\title{
South Korea's Defense Posture against the North Korean Nuclear Threat: Dangerous Reluctance
}

\author{
HWEE-RHAK PARK*
}

\begin{abstract}
This paper examines South Korea's defense preparedness against a possible North Korean nuclear attack. It applies three options of nuclear defense: preemptive attack against North Korean nuclear weapons and facilities, interception of airborne North Korean nuclear missiles, and civil defense to reduce casualties from a nuclear explosion. North Korea may have succeeded in developing about 10 nuclear weapons and making them small and light enough to be delivered by its ballistic missiles. It is imperative for South Korea to prepare defenses against a nuclear attack in the case its diplomatic efforts and deterrence measures fail. South Korea needs to be able to conduct a preemptive strike when a North Korean nuclear attack is imminent. It should also build up its ballistic missile defense systems in order to intercept any North Korean nuclear missiles that may survive a preemptive strike. Moreover, South Korea should prepare for its civil defense by constructing blast and/or fallout shelters to help more people survive a possible nuclear explosion.
\end{abstract}

Keywords: North Korea, Nuclear Weapon, Nuclear Missile Threat, Preemptive Strike, Missile Defense, Civil Defense

\footnotetext{
*Associate Professor, Kookmin University, Seoul, Korea;

E-mail: hrpark5502@hanmail.net;

DOI: 10.16934/isr.16.1.201506.41
} 


\section{INTRODUCTION}

North Korea may have succeeded in acquiring "nuclear operationality" (Moore 2005). It has been reported that North Korea may have developed about 10 nuclear bombs using the materials it extracted from its Yongbyon nuclear reactor (MND 2014, 28). The regime of North Korea also announced that it succeeded in making them small and light enough to mount on its ballistic missiles just after its third nuclear test on February 12, 2013. Based on this information, if North Korea feels that it is being provoked then it could attack South Korea with its nuclear missiles. The question to pose is, does South Korea have the relevant capabilities to defend against such an attack?

South Korea has been depending on diplomatic solutions, such as the SixParty Talks, to make North Korea surrender its nuclear programs and dismantle any possible nuclear bombs. Hopes were high for the Six-Party Talks in 2005, when North Korea agreed to de-nuclearize itself in exchange for the construction of two light-water nuclear reactors, which South Korea, the U.S., and Japan promised to provide. However, neither side kept their promises. The diplomatic solutions have not progressed beyond rhetoric. The U.S. and South Korea's diplomatic efforts have failed to persuade North Korea to stop its nuclear weapons program (Kwon Edward 2014, 499).

South Korea also depends on the U.S. promise of an extended deterrence or a nuclear umbrella to deter a possible North Korean nuclear attack. South Korean former National Assembly member Jung Mong-jun has made accusations that the concept of a nuclear umbrella is "broken" (Lee 2013, A5). That has led many South Koreans to be skeptical of the reliability of the U.S. promise. In fact, it would not be easy for the U.S. to retaliate against a North Korean nuclear attack on South Korea. The retaliation could provoke a North Korean nuclear attack on U.S. bases in South Korea, Japan, and U.S. territories, which are within the reach of North Korean ballistic missiles. It could also lead to an all-out nuclear war with China and/or Russia. Recognizing these difficulties, North Korea may decide to employ its nuclear weapons in the belief that the U.S. will not retaliate (Ham and Lee 2013, 411).

It is high time for South Korea to shift the focus on its preparedness against the North Korean nuclear threat from deterrence to defense. Some scholars believe that South Korea would have no choice but to endure "the unpleasant, unwanted and unacceptable living with" a nuclear armed North Korea (Moore 2014, 75-76). However, it is the South Korean government's mission to protect its people from any threats under any circumstance. The South Korean government should be determined to do everything necessary to defend its people from a possible North Korean nuclear attack. South Korea even needs to consider its civil defense for the worst-case scenario as well as ballistic missile defense (BMD) and a preemptive strike. 
Currently, the South Korean defense posture against North Korean nuclear weapons is limited. It does not have interceptor missiles with "hit-to-kill" capabilities and sophisticated intelligence assets to identify and analyze the movement and launch of North Korean nuclear missiles. It has never discussed the necessity of a civil defense. South Korea seems reluctant to move from deterrence to defense, even though the situation dictates such a move.

This paper will examine the key types of nuclear defenses as a starting point of a discussion. It will evaluate South Korea's current nuclear defense readiness level by applying the aforementioned types of nuclear defense. In its conclusion, it will draw several lessons that South Korea should learn in its policies addressing the North Korean nuclear threat.

\section{THREE TYPES OF NUCLEAR DEFENSE}

\section{Ballistic Missile Defense}

North Korea could try to drop its nuclear weapons on South Korean cities using its aircraft. However, the sophisticated air defense systems of South Korea can detect the take-off of all North Korean aircraft, track their flights, and intercept them in the air. While recognizing this level of sophisticated anti-aircraft capabilities of South Korea, North Korea has been trying to make its nuclear weapons small and light enough to deliver by ballistic missile. Ballistic missiles can fly fast and long-range and carry about a one-ton payload. Above all, current technologies cannot effectively detect and destroy the ballistic missiles in the air before they reach their target.

The U.S. has been developing technologies to intercept ballistic missiles since the 1980s. Thanks to its long-term investment, it eventually developed the hit-to-kill technology in the first years of the 21 st century and has been improving it. The effectiveness of this technology, however, is still far from perfect. Therefore, the U.S. organized a multi-layered defense system in order to increase the probability of intercepting a ballistic missile. The system has been divided into the boost phase, midcourse phase, and terminal phase. The US has also tried to develop appropriate weapon systems for each phase to protect the mainland. It also wants to protect its forward deployed forces from short-range and lowaltitude attacking missiles with the Theater Missile Defense (TMD). The U.S. divided the TMD into a boost phase, an upper-tier defense of terminal phase, and a lower-tier defense of terminal phase. South Korea, which has to intercept attacking North Korean missiles from a short distance, should apply this TMD concept for its BMD.

The U.S. currently has 30 Ground-based Interceptors in California and Alaska for its mid-course phase defense. It is planning to increase the number to 44 by 
2017. It has 30 AEGIS destroyers, which have SM-3 interceptor missiles. It also has developed the Theater High Altitude Areas Defense (THAAD) and Patriot Advanced Capabilities (PAC)-3 as part of its terminal phase defense. Although there is no reliable information about the BMD of Russia and China, they are believed to be developing similar missile defense systems.

If one has effective BMD capabilities, meaning one can destroy all incoming missiles in the air before they land, then one can make an enemy's nuclear weapons useless. Christopher R. Hill, who participated in the nuclear negotiations with North Korea as a representative of the U.S., mentioned that "missile defense could ultimately become the game-changer toward North Korea" (Hill 2013, 18). However, it is very difficult to build-up sufficient BMD capabilities to intercept all attacking nuclear missiles. BMD capabilities could be an important and safe part of a nuclear defense, but could not take the entire responsibility of the defense alone.

\section{Preemptive Strike}

A preemptive strike refers to an action to destroy enemy's nuclear missiles before their launch. It is "an attack initiated on the basis of incontrovertible evidence that an enemy attack is imminent" (DoD 2010, 288). It is different from a preventive attack, which is carried out when the adversary's attack is not imminent and the cost and/or risk would be lower now than later (Warren 2012, 8-9). Therefore, preemption is accepted as reasonable option, while prevention is regarded as excessive. A preemptive strike at an enemy's nuclear weapons is imperative, especially for a country that does not have effective BMD because a nuclear attack can cause huge damage and deprive the defender of the opportunity to counterattack.

Some scholars of international law argue that a preemptive attack should be recognized as a legitimate measure of self-defense (Arend 2003, 102; Szabo 2011, 2; Sofaer 2003). A report from the office of the UN Secretary General in 2004 mentioned that a military action can be taken in advance when "the threatening attack is imminent, no other option can mitigate the threat, and the action is proportionate" (United Nations 2004, 63). Several scholars in South Korea agree to the above arguments (Kim 2009, 7; Jhe 2010, 73; Kim 2004, 260).

There have been several preemptive attacks by conventional forces in recent history. Israel attacked and defeated Egypt preemptively in 1956, when it recognized that Egypt was going to block the Suez Canal. It attacked surrounding Arab countries preemptively in 1967, when it learned that these countries had begun full mobilization and deployment of their forces to its border areas (Kwon 2012, 8990). The U.S. executed a surgical strike at the presidential office of Libya on April 14, 1986, when it acquired evidences of an imminent terror attack on the U.S. by Libya. 


\section{Civil defense}

The last defense measure against a nuclear attack is a civil defense. If we do not take any necessary measure for the worst case-a nuclear explosion in our city-a single nuclear missile attack by the enemy can cause devastating and irreparable damage. That is the reason why the U.S., the USSR, and European countries began a civil defense during the Cold War, even though they adopted the Mutual Assured Destruction (MAD) strategy for nuclear deterrence.

A nuclear explosion kills many people by its strong blast, heat, and fatal radiation. According to a simulation, if a 15 kiloton nuclear bomb exploded in Seoul at an altitude of 500 meters, there would be about 620,000 casualties. If the bomb exploded at 100 meters high, casualties would increase to 840,000. If the bomb went off at a ground level, 1,250,000 casualties would result (McKinzie and Cochran 2004).

There are three types of measures to reduce the casualties from a nuclear explosion. The first one is to construct shelters to protect people from the explosion or fallout of the explosion. The second one is to evacuate people from dangerous area to safe areas. The third one is an early warning of a nuclear attack and communications with people before, during, and after the nuclear attack. A main purpose of a civil defense should be to make people know about the nuclear explosion and the best ways to survive it.

Construction of suitable shelters for the entire population involves a huge investment. Shelters require thick walls, doors, and roofs to allow people to survive the powerful blast. The blast of a 10-20 kilo ton nuclear bomb cannot reach more than a 1-2 km diameter from ground zero (National Security Staff 2010, 16). Therefore, most countries focus on the construction of fallout shelters, which provide protection from nuclear fallout for the people outside ground zero. Although the fallout shelters need to have thicker walls and roofs of more than $30 \mathrm{~cm}$ of concrete, $40 \mathrm{~cm}$ of brick, or $90 \mathrm{~cm}$ of soil (FEMA 1985, 18), they are not that difficult to build. The shelters should provide necessary items for the people inside to survive for at least two weeks, which is the minimum time period necessary for nuclear radiation to decrease enough for people to exit.

For example, Switzerland has built robust fallout shelters and some blast shelters for use in case of a nuclear explosion. One of its shelters, the Sonnenbourg Tunnel, accommodates about 20,000 people and provides sustenance for two weeks. The U.S. also started to construct fallout shelters in the 1960s, when President John F. Kennedy emphasized the possibility of nuclear attack by an irrational opponent (Homeland Security 2006, 12). Russia, the successor state to the USSR, may have well-prepared shelters throughout the country, because the USSR emphasized a civil defense as a key part of its nuclear deterrence strategy (Green 1984, 7). 
The purpose of a civil defenses' evacuation policy should focus on moving people from dangerous areas to safer areas. If we assume that nuclear missiles usually target key military facilities, the people around these areas could be evacuated before the attack. An exaggerated or erroneous evacuation order can cause people to be exposed to nuclear radiation on the road and cause massive sudden social unrest and disorder. An evacuation order should be issued in a cautious matter and be based on accurate intelligence to ensure the mass movement of a population to a safe area (Connor 2013,3).

The purpose of civil defense warning measures should be to notify people of an imminent or ongoing nuclear attack. Based on the warning, people would move to shelters or evacuate. Government efforts to communicate with the population using radio or other means can keep people calm and ensure that they take appropriate steps for survival. Government communications with people inside nuclear shelters allows the people to make informed decisions, including whether to stay in or go out of these shelters.

\section{Discussion on Defensive Options}

All defensive options against a nuclear attack, such as interception, preemption, and civil defense, are closely related. If a country lacks interception capabilities, it should reinforce its preemptive strike capabilities. If it lacks interception and preemption capabilities, it should invest more energy and money in a civil defense.

The safest option of the above three options is the interception of incoming enemy nuclear missiles, which should be implemented by a BMD. If a country had perfect interception capabilities, the enemy's nuclear missiles would be worthless. Current technologies cannot guarantee the "hit-to-kill" probabilities of all nuclear missiles in the air because of the fast speed of the missiles. Simultaneously, it is expensive for a country to construct a BMD that seamlessly covers its entire territory. Interception is an ideal option but is not reasonably attainable.

Preemption can reduce the burden of BMD in advance. It will destroy the enemy's nuclear missiles before they are launched. A country should have accurate intelligence on the exact location of a nuclear missile before a preemptive strike and also have proof of the imminence of an attack. Without this information, an unsuccessful preemptive attack can escalate the situation into an all-out nuclear attack by the enemy.

A civil defense is the last option upon which a country should depend. It can reduce damage and save lives from a nuclear explosion. A civil defense can be regarded as an insurance policy for unsuccessful defensive options.

The normal order of employment for the three defensive options appears in Figure 1, which describes the mitigating effects of the options. 


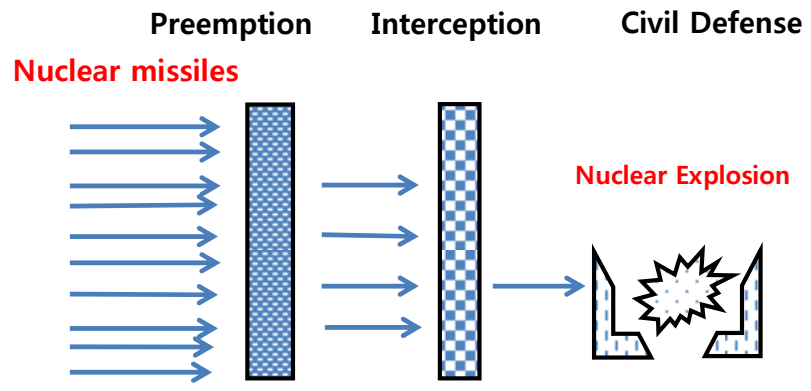

Figure 1. Mitigation EfFects of Nuclear DefEnse Options

According to Figure 1, a country facing an enemy nuclear attack should apply preemption first, interception or BMD second, and a civil defense last in a timebased manner. However, the preparation priority will not necessary match with the order. Some countries focus on BMD and others on preemption based on the distance, capabilities, and circumstances. If a country cannot be sure about the effectiveness of its preemption strategy or its BMD capabilities, then it should rely on its civil defense as the only feasible option.

\section{ASSESSMENT OF NORTH KOREAN NUCLEAR THREAT}

North Korea has conducted three nuclear explosion tests since it started to develop nuclear weapons in the 1970s. The first test was on October 9, 2006, the second on May 25, 2009, and the third on February 12, 2013. The third test demonstrated a detonation power commensurate to six to seven kilotons of TNT (Yoo 2013, A1). North Korea is believed to have developed about 10 nuclear bombs so far (Kristensen 2014, 97).

Simultaneously, North Korea has accelerated its efforts to produce a more sophisticated and miniaturized nuclear warhead that can be installed on intermediate and intercontinental ballistic missiles (Kwon 2014, 487-488). As a result, North Korea announced that it was successful in its nuclear explosion test using a smaller bomb for its third test (Yoo 2013, A1). The South Korean Defense White Paper also recognized the North Korea's success at making smaller nuclear weapons (MND 2014, 28).

North Korea could make more nuclear weapons using highly enriched uranium (HEU). It displayed a numerous amount of centrifuges, which is the key to HEU and to American scientists including Sigefried Hecker in November 2010 (Hill 2013, 9). It doubled the facility's size and may have additional secret facilities in other areas (Kim 2013, 38). North Korea might have produced enough highly enriched HEU for a lightweight nuclear bomb (Kwon 2014, 490). Based on these efforts, North Korea is believed to have improved the quantity and quality of its 
nuclear weapons. David Albright, an American physicist, projected that North Korea may have 100 nuclear weapons in 2020 in a worst case scenario (Albright 2015, 28).

Although extended deterrence of the U.S. missile defense systems would generally restrain North Korea from using nuclear weapons, nobody could exclude the possibility of North Korea using nuclear weapons. Ham and Lee state: "North Korea has recently announced its plan to use its nuclear weapons not only for the purpose of deterrence in peacetime, but also to achieve victory in possible future wars" $(2013,410)$. In fact, North Korea once ordered its strategic rocket and artillery forces to maintain "the first degree combat readiness," which was understood as nuclear attack readiness, on March 27, 2013. North Korea passed a law, which stipulated the authority and possible situations for the use of nuclear weapons on April 1, 2013. The law read that North Korea could use its nuclear weapons on a "belligerent nuclear power and a country that opposes North Korea by cooperating with the belligerent nuclear power ... by the order of its Supreme Commander" (Kwon Tae 2014, 192).

No one can be sure of the actual nuclear capabilities and intentions of North Korea due to the lack of reliable intelligence. However, for its own safety, South Korea should be prepared for the worst case scenario. As Ham and Lee put it, "As North Korea's nuclear arsenal becomes larger and more advanced, North Korea will become better able to dissuade nuclear retaliation or attacks from other states. This, in turn, will increase the possibility of North Korea's usage of its nuclear weapons and the number of nuclear weapons to be used" $(2013,410)$. South Korea should not avoid the serious reality mentioned above.

\section{SOUTH KOREAN DEFENSE-PREPAREDNESS LEVELS FOR NORTH KOREAN NUCLEAR THREATS}

\section{Interception}

South Korean preparedness to intercept incoming North Korean nuclear missiles through the use of a BMD appears to be poor due to its lack of hit-to-kill missile capabilities. The Kim Dae-jung and Roh Moo-hyun administrations did not discuss a BMD for fear of provoking North Korea. Although the subsequent Lee Myung-bak administration changed the policy and started to construct the "KAMD" (Korea Air and Missile Defense), it failed to achieve any significant result. The KAMD was limited to a lower-tier defense in order not to offend civilian activists who demanded that South Korea should not be a part of the U.S. BMD (Jung Uk 2003). The KAMD itself combined an air defense and a ballistic defense. As a result, South Korea purchased PAC-2 and SM-2 missiles, which was effective for anti-aircraft defense but not for anti-missile defense.

The most influential factor on of the South Korean BMD was the propaganda 
of civilian activists, who reflected an anti-American sentiment. They argued that the South Korean BMD would become part of the U.S. BMD, which could damage China's strategic interests and sour South Korea-China relations (Pyeonghwa-wa 2008). They obstructed all government attempts at a BMD by appealing to the people's anti-American emotions in South Korea. They blocked the government's review on THAAD or SM-3 anti-ballistic missiles, while only allowing the PAC-3 short-range anti-ballistic missiles.

In order not to provoke the opposition, the South Korean government bought two Green Pine radar sets not from the U.S. but from Israel in 2012. It recently decided on the purchase of 136 U.S. PAC-3 missiles (Kang 2014). However, it would not discuss buying THAAD or SM-3 medium range interceptor missiles from the U.S. Recent American moves to deploy its THAAD systems for its forces in Korea, met strong opposition by the civilian activists. As a result, the current South Korean BMD capabilities are limited and cannot protect people from a possible North Korean nuclear missile attack.

\section{Preemptive Strike}

Due to the limitations and hurdles regarding its BMD capabilities, South Korea had to emphasize the necessity of a preemptive strike. The South Korean chairman of the Joint Chiefs of Staff in the year of 2013, Jung Seung-jo, made clear that he would "strike North Korean nuclear weapons in self-defense, if there is a clear evidence of an attack" just before North Korea's third nuclear test in February 2013 (Jeon 2013, A1). Since that time, the South Korean military developed plans and capabilities for preemption under the rubric of a "kill chain," which meant a complete process to destroy the emerging targets as quick as possible. Based on this concept, the South Korean military is planning to acquire advanced surveillance equipment such as Global Hawk, unmanned reconnaissance aircraft, and stealth fighter/attacker aircraft such as F-35, but none of them has yet been acquired. Preemption exists only as a concept for the South Korean military for now.

In fact, preemption itself is not a reliable option, because South Korea does not have sufficient capabilities to acquire intelligence on the locations and movements of North Korean nuclear missiles. It does not have its own military reconnaissance satellite, and its spy aircraft are hardly able to watch all places in North Korea continuously. North Korea will take every measure to avoid South Korean surveillance. Although the U.S. provides South Korea with accurate intelligence, American forces cannot identify all the movement of North Korean nuclear missiles. As a fact of this, South Korea and the U.S. failed to identify the movement or the launch of North Korean short-range ballistic missiles on July 13, 2014 (Yoo 2014, A5). 


\section{Civil Defense}

South Korea has emphasized civil defense since the 1970s, when South Vietnam was conquered by communist North Vietnam. The focus was on preparing the population for North Korean air strikes in a conventional war. However, the long armistice made the South Korean people unconcerned about war, and South Korea gradually decreased the level of a civil defense. Although South Korea maintains about four million civil defense forces, the training time has been reduced from 29 hours per year at its peak in the 1970s to the current four hours per year. It reduced civil defense drills from 12 times per year in the 1970s to 8 times and changed the focus of five drills out of eight into preparation for natural or artificial disasters. The national or local organizations for a civil defense have contracted, and many problems have been reported regarding the civil defense's organizations, operations, facilities, equipment, and training (Jung 2011, 15). South Korea designated many civil defense shelters throughout the country, but the number, size, and quality of the shelters have decreased since the 1980s (KICT 2008, 34-46).

South Korea has never discussed civil defense with the assumption of a North Korean nuclear attack. The newly created Public Safety Agency is responsible for a civil defense, but it did not expand its mission to civil defense for a nuclear war. Even scholars have been reluctant to talk about the necessity of a civil defense in the nuclear age. This author published two articles on nuclear civil defense in 2014 (Park 2014a; Park 2014b) but failed to raise popular or scholarly interests. The only glimpse of an active civil defense in South Korea is Traum House, which is one of the most expensive villas in Seoul. Traum House constructed its own nuclear shelters for its residents. It boasts that its shelters have 70cm-thick concrete walls and enough capacity to accommodate 200 people for 20 days (Home Page).

\section{Assessment}

South Korea does not have sufficient capabilities in the three defensive options against a nuclear attack: the interception of incoming nuclear missiles, a preemptive strike at nuclear weapons and facilities, and civil defense for a possible nuclear detonation. South Korea can make a rapid improvement if it renders intensive investment into preemption capabilities. The capabilities for interception and civil defense, however, would involve a longer time frame and more efforts than those for preemption. South Korea's weakness in these areas would continue with little improvement in the near future.

Since South Korea does not have effective capabilities for a preemptive strike, it cannot intercept a launched North Korean nuclear missile in the air. Therefore, the burden of defense against a nuclear attack should be placed on a civil defense. 
Until South Korea secures the necessary capabilities for a successful preemptive strike, and reliable BMD systems, it may have no option but to prepare for a civil defense. This situation is depicted in Figure 2, which describes the limited mitigation effects of South Korean nuclear defense options.

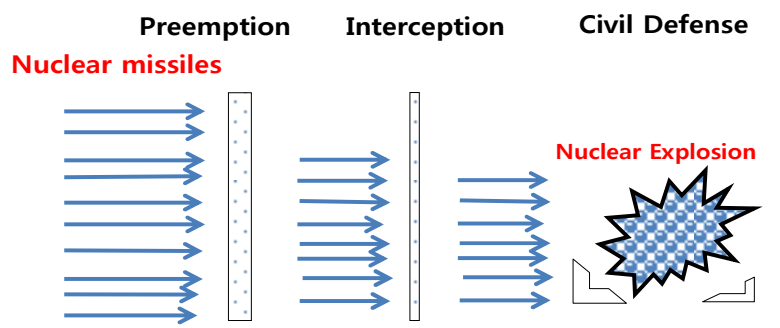

Figure 2. Mitigation EfFects of SOUth Korean Nuclear DefEnse Options

As demonstrated in Figure 2, a preemption option of South Korea cannot meaningfully reduce the magnitude of the North Korean nuclear threat due to lack of capabilities for it. The second defense, interception or BMD of South Korea, cannot reduce the threat significantly. South Korea does not have a comprehensive concept or capabilities for its own BMD. The last option is South Korean civil defense, which cannot mitigate any effects of a nuclear explosion, since it was never discussed. South Korea should strengthen all three options together, while giving the first priority to the first wall, preemption, since it can be reinforced in a relatively short period of time.

\section{LESSONS FOR SOUTH KOREA}

\section{Consensus on Nuclear Defense}

The South Korean people and decision-makers need to recognize that the current situation compels South Korea to mobilize all defensive options. No one can rule out the possibility of North Korea's use of its nuclear missiles. South Korea, however, has no effective means to defend itself.

In addition to trying to persuade North Korea to surrender nuclear weapons, South Korean leaders should try to answer the following question: "How do we protect our own people from a North Korea attack with nuclear missiles?" They should discuss various ways to intercept North Korean nuclear missiles in the air, to preempt them before their launch, and to minimize the damage from nuclear detonations. Although these contingencies are not pleasant ones to discuss, the leaders should face reality. They need to improve the effectiveness of each option and find the best combination of all options.

As a starting point for a full-fledged defense against the North Korean nuclear 
threat, South Korea may need to establish an organization to analyze the imminence and magnitude of the nuclear threat and orchestrate all necessary defensive measures. Such an organization can ensure the unity of efforts, consistency and efficiency in a nuclear defense. The South Korean military should transform its organizations to concentrate all efforts on a nuclear defense.

\section{Construction of $B M D$}

First of all, the South Korean people should not buy the propaganda that if South Korea builds its own BMD, it would become a part of the U.S. BMD. This is a grave accusation that a few anti-government activists have spread to block cooperation with the U.S. South Korea needs its own BMD in order to protect its people from a possible North Korean nuclear missile attack. It will be effective and efficient for South Korea to build its BMD through close cooperation with the U.S., which has developed the most advanced BMD systems and has been a strong ally of South Korea for more than 60 years. It is total nonsense if South Korea does not cooperate with the U.S. on a BMD, because South Korea maintains the Combine Forces Command with the U.S. forces to deter and defeat North Korean aggression including a nuclear attack.

As a meaningful start, South Korea should acquire, as planned, several PAC3 batteries as soon as possible in order to provide the lower-tier terminal phase BMD to key strategic facilities. It also should conduct a cost-effectiveness analysis on the purchase of THAAD systems, which could provide the upper-tier terminal phase of a BMD. If the USFK decides to deploy its own THAAD systems on South Korean soil, South Korea should welcome the decision and use the opportunity to check all the details of THAAD. South Korea may need to discuss the relevance and cost-effectiveness of the SM-3 sea-based interceptors, in order to cover the limitations of PAC-3 and THAAD.

South Korea needs to strengthen its cooperation with the U.S. and Japan especially regarding a BMD against North Korea. Close coordination and consultation among these three nations could increase the probability of destroying North Korean nuclear missiles. The recent agreement among South Korea, the U.S. and Japan for sharing intelligence regarding the North Korean nuclear threat should be used as a basis for more comprehensive cooperation around building a BMD for South Korea.

\section{Detailed Plans and Intelligence for Preemptive Strike}

The first demanding task of the South Korean government for the success of a preemptive strike is to build a national consensus on the inevitability of this option. An early preemptive strike would increase the likelihood of success but 
could escalate tension abruptly and dissuade international support. A late preemptive strike would increase the legitimacy of the action but could reduce the probability of success. The government of South Korea should discuss appropriate terms and procedures with the policy makers so that when crises occur, the president and other key cabinet members can decide to attack North Korean nuclear weapons preemptively. It should develop detailed criteria by which to judge the imminence of a North Korean nuclear attack.

The quality of intelligence is the most important factor regarding the success or failure of a preemptive strike. The South Korean government should have the capability to identify the total number, locations, and movement of North Korean nuclear weapons in order to effectively target to destroy them. In this sense, South Korea needs to send highly trained human intelligence teams and collect reliable intelligence on North Korean nuclear attack capabilities. Additionally, it should construct a comprehensive database for intelligence and establish cooperation mechanisms with the U.S. and Japan.

The South Korean armed forces should be prepared to conduct any preemptive strike order successfully under any circumstances. They should develop creative, feasible, and detailed plans to execute the order. Leaders of the armed forces should create organization that selects and trains teams to implement these plans. They should also make it their first priority to acquire the necessary equipment and weapons for these plans.

South Korea should be prepared to conduct a preemptive strike on its own, if unavoidable. However, if it receives the support of the U.S., the probability of success will dramatically increase and the risk of the strike will be significantly reduced. South Korea should consult with the U.S. continually discuss the most effective ways to degrade North Korean nuclear capabilities. It may be a high time for leaders of South Korea government to reconsider all the options on the table with the U.S.

\section{Preparation for Civil Defense}

Because South Korea cannot be sure of the success of its nuclear deterrence, or of its intercepting incoming nuclear missiles, and because it cannot guarantee the success of a preemptive strike against North Korean nuclear weapons, South Korea should not ignore the necessity of civil defense for a possible nuclear explosion. Although civil defense cannot protect everyone, it can help reduce casualties.

The South Korean government needs to start discussions on civil defense in the nuclear age and designate a responsible organization to make plans and guide the people on civil defense. The People's Safety Agency, established in December 2014, should assume this responsibility. The agency should develop the concept, policies, guidelines, and specific projects for the civil defense of the South Korean 
people. It should adopt a new warning system for a nuclear attack and prepare the necessary messages in advance to advise the people to respond wisely to a nuclear detonation (see FEMA 2013). It needs to conduct exercises for the people to survive in shelters and to evacuate to safer places.

The South Korean people should seriously consider the need to build public blast and/or fallout shelters against nuclear detonation. If the cost of new shelters becomes expensive, then it is possible to renovate existing non-nuclear shelters and to transform underground spaces such as buildings, subways, parking lots, and houses into nuclear shelters. The government might also offer tax credits to encourage independent shelters.

\section{CONCLUSIONS}

No one in the world likes to face a nuclear war, but we must face the reality. If we do not prepare for the worst-case scenario, we cannot prevent it. Now that North Korea has developed several nuclear bombs and succeeded in making them small enough to deliver with ballistic missiles, then the possibility of a nuclear attack by North Korea becomes reality.

The only feasible option against a North Korean nuclear attack at this point is preemption. Tactically, South Korean Air Forces with F-15 and F-16 fighters have sufficient capabilities to identify and destroy targets. Moreover, F-35 fighters will embolden South Korean strike capabilities in a few years. However, these continuous efforts of modernizing South Korea striking capabilities do not fully prepare the country against attack from North Korea due to the lack of intelligence. The leaders of South Korea should make intensive efforts to improve the quality of intelligence on North Korean nuclear weapons.

South Korea should build its own BMD systems as soon as possible to be prepared for the failure of a preemptive strike. It should purchase PAC-3 shortrange interceptors as planned for its lower-tier defense and assesses the relevance of THAAD intermediate range interceptors for its upper-tier defense. South Korea should cooperate closely with the U.S. and Japan in regarding to construction and operations of its BMD.

South Korea should prepare for a civil defense against the worst-casescenario: a nuclear bomb explosion in Seoul and its metropolitan areas. The South Korean government needs to designate an organization, such as a Public Safety Agency, to be responsible for policies and guidelines, and to construct public blast and/or fallout shelters. The South Korean people should aware of location of the nearby shelters and fully prepared to survive at least two weeks.

As the Roman adage goes, "If you want peace, prepare for war." If South Koreans wish to survive, they should do everything necessary to protect themselves from the North Korean nuclear threat in advance. 


\section{REFERENCES}

Albright, David. 2015. Future Directions in the DPRK's Nuclear Weapons Program: Three Scenarios for 2020. North Korea's Nuclear Futures Series. U.S.-Korea Institute at SAIS. Accessed on May 2, 2015. http://38north.org/wp-content/ uploads/2015/02/NKNF-Future-Directions-2020-Albright-0215.pdf.

Arend, Anthony Clark. 2003. International Law and the Preemptive Use of Military Force. The Washington Quarterly (Spring): 89-104.

Connor, Shane. 2013. The Good News about Nuclear Destruction. Threat Journal (August 6). Accessed on April 20, 2015. http://goodnewsnuke.com/.

Department of Defense. 2010. Military and Associated Terms. As Amended Through 31 January 2011. Washington D.C: DoD. (November 8).

Department of Defense. 2013. Military and Security Developments Involving the Democratic People's Republic of Korea. Washington D.C.: DoD.

FEMA (Federal Emergency Management Agency). 1985. Protection in the Nuclear Age. Washington D.C: FEMA.

FEMA. 2013. Improved Nuclear Device Response and Recovery: Communicating in the Immediate Aftermath: Washington D.C: FEMA.

Green, Brian. 1984. The New Case for Civil Defense. Backgrounder (August 29). Accessed on May 5, 2015. http://www.heritage.org/research/reports/1984/08/ the-new-case-for-civil-defense.

Ham, Hyeongpil and Jaehak Lee. 2013. North Korea's Nuclear Decision-making and Plausible Scenarios. The Korean Journal of Defense Analysis 25(3): 399413.

Hill, Christopher R. 2013. The Elusive Vision of a Non-/nuclear North Korea. The Washington Quarterly 36(2): 7-19.

Homeland Security National Preparedness Task Force. 2006. Civil Defense and Homeland Security: A short History of National Preparedness Efforts. Washington D.C.: Department of Homeland Security.

Jhe, Seong-Ho. 2010. The Right of Self-defense under the United Nations

Charter: Revisited. Seoul-Guk-Je-Byeob-Yeon-Gu (Seoul International Law Journal) 17(1): 65-93.

Jun, Seok-Hyun. 2013. 합참의장 '북 수소폭탄 전단계 핵실험 가능성.' (Chairman of JCS said that North Korea likely conduct nuclear test as pre-stage of a hydrogen bomb). Chosun-ilbo (Chosun Newspaper). February 7. Accessed May 5, 2015. http://srchdb1.chosun.com/pdf/i_service/pdf_ReadBody.jsp? $\mathrm{Y}=2013 \& \mathrm{M}=02 \& \mathrm{D}=07 \& \mathrm{ID}=2013020700151$.

Jung, Su-Sung. 2011. 2011 Guk-Jeong-Gam-Sa Ja-Ryo-Jip II: Min-Bang-Wi HunRyeon-Ui Nae-Sil-Hwa Bang-An. (Records of Audit of the Government by the National Assembly 2011 II: Options to Improve the Exercise of Civil Defense). The office of the Representative Jung, su-sung. 
Jung, Uk-Sik. 2013. Missile Bang-Eo-Che-Je (Missile Defense System). Seoul. Salim Pub.

Kang, Eui-Won. 2014. 정부, 미국서 PAC-3 도입한다. (South Korea will purchase PAC-3 from the U.S.). Yonhapnews Agency. November 7. Accessed May 5, 2015. http://www.yonhapnews.co.kr/bulletin/2014/11/07/02000000 00AKR20141107012700071.HTML?input $=1179 \mathrm{~m}$.

KICT (Korea Institute of Civil Engineering and Building Technology). 2008. A Study on Options for the Construction of Underground Shelters against Nuclear Explosion (written in Korean). A Project for Ministry of Land, Infrastructure and Transport, Project No. 2008-008.

Kim, Chan-Gyu. 2009. The Changing Concept of Armed Attack and Its Impact on the Law of Self-Defense. In-Do-Byeob-Non-Chong (The Korean Journal of Humanitarian Law) 2: 3-22.

Kim, Dong-Su et al. 2013. 2013-nyen Buk-han Hae-program-mit Neung-ryeok Pyeong-ga (An Assessment of North Korean Nuclear Programs and Capabilities in $2013 \mathrm{KINU}$ Policy Serious. Seoul: Korea Institute for National Unification.

Kim, Hyeon-Su. 2004. A Study on the Exercise of Right of Self-defense in International Law (written in Korean). Hae-Yang-Jeon-Ryak (Maritime Strategy) 123: $245-278$.

Klingner, Bruce. 2011. The Case for Comprehensive Missile Defense in Asia. Backgrounder (Heritage Foundation). No. 2506 (Jan 7). Access on April 20, 2015. http://www.heritage.org/research/reports/2011/01/the-case-for-compre hensive-missile-defense-in-asia.

Kwon, Edward. 2014. The U.S.-ROK Alliance in Coping with North Korea's Nuclear Threat. The Korean Journal of Defense Analysis 26(4): 487-503.

Kwon, Hyuk-Chul. 2012. An Analysis and Strategic Lessons from the Implementation of Anticipatory Self-defense: Focused on the Case Study of Sixday War Guk-bang-jeong-chaek-yeon-gu (Quarterly Journal Of Defense Policy Studies) 28(4): 81-110.

Kwon, Tae-Young. 2014. Buk-Han Haek-Missile-Wi-Hyeop-Gwa Dae-Eung (North Korean Nuclear Missile Threat and South Korean Response). Seoul: Bookkorea pub.

Lee, Ha-Won. 2013. 정몽준 '미 핵우산 찢어져'. (The U.S. nuclear umbrella has broken). Chosun-ilbo (Chosun Newspaper). February 20. Accessed May 5, 2015. http://srchdb1.chosun.com/pdf/i_service/pdf_ReadBody.jsp?Y=20 $13 \& \mathrm{M}=02 \& \mathrm{D}=20 \& \mathrm{ID}=2013022000152$.

Li, Bin. 2010. An alternative view to North Korea's bomb acquisition. Bulletin of the Atomic Scientists (May/June). Accessed on March 1, 2015. http://the bulletin.org/2010/may/alternative-view-north-koreas-bomb-acquisition.

McKinzie, Matthew G. and Thomas Cochran. 2004. Nuclear Use Scenarios on the 
Korean Peninsula. Natural Resources Defense Council. prepared for the Seminar on International Security Nanjing. China (October 12-15). Accessed on February 1, 2015. http://docs.nrdc.org/nuclear/files/nuc_04101201a_239. pdf.

MND (Ministry of National Defense). 2010. 2010 Guk-Bang-Baek-Seo (Defense White Paper) (written in Korean). Seoul: Ministry of National Defense.

MND. 2012. 2012 Guk-Bang-Baek-Seo (Defense White Paper). Seoul: Ministry of National Defense.

MND. 2014. 2014 Guk-Bang-Baek-Seo (Defense White Paper). Seoul: Ministry of National Defense.

Moore, Gregory J. (eds). 2014. North Korean Nuclear Operationality. Baltimore, Johns Hopkins Univ. Press.

National Security Staff Interagency Policy coordination Subcommittee. 2010. Planning Guidance for Response to a Nuclear Detonation. 2nd edition. FEMA. Park, Hwee-Rhak. 2014a. A Comparative Study on Civil Defense Regarding Nuclear Attack: Focused on Preparedness against North Korean Nuclear Weapons. Pyeong-Hwa-Yeon-Gu (Journal of Peace Studies) 15(5): 81-106.

Park, Hwee-Rhak. 2014b. A Reinforcement of South Korean Nuclear Deterrence Strategy: Focused on the Inclusion of Nuclear Civil Defense. Guk-Ga-JeonRyak (National Strategy) 20(3): 41-70.

Pyeong-hwa-wa Tong-il-eul Yeo-neun Sa-ram-deul. 2008. Mi-Guk MD-E ChamYeo Gyu-Tan Gi-Ja-Hoe-Gyeon-Mun (Press Release Denouncing the Participation in the U.S. Missile Defense). March 20.

Sofaer, Abraham D. 2003. On the Legality of Preemption. Was the war in Iraq legal? hoover digest (April 30). Accessed on February 1, 2015. http://www.hoover. org/publications/hoover-digest/article/6590.

Szabo, Kinga Tibori. 2011. Anticipatory Action in Self-Defense: Essence and Limits under International Law. Hague: Springer.

Traum House Homepage. Accessed on May 5. http://www.traumhaus.co.kr/sub traum_02.asp.

United Nations. 2004. A More Secure World: Our Shared Responsibility. Report of the High -level Panel on Threats, Challenges and Change. United Nations. Accessed on May 5, 2015. http://www.un.org/en/peacebuilding/pdf/histrical/ hlp_more_secure_world.pdf.

Warren, Aiden. 2012. Prevention, Pre-emption and the Nuclear Option. New York: Routledge.

Yoo, Yong-Won. 2014. 북, DMZ $20 \mathrm{~km}$ 코앞서 미사일 기습 발사. (North Korea launched missiles surprisingly at the $20 \mathrm{~km}$ north from the DMZ). July 14. Accessed May 5, 2015. http://srchdb1.chosun.com/pdf/i_service/pdf_Read Body.jsp?Y=2014\&M=07\&D=14\&ID=2014071400151.

Yoo, Young-Won. 2013. 북 '미국이 적대적으로 나오면 2·3차 대응 조치.' 
(North Korea will take the second and third responsive measures, if the U.S. remain antagonistic). Chosun-ilbo (Chosun Newspaper). February 13. Accessed May 5, 2015. http://srchdb1.chosun.com/pdf/i_service/pdf_ReadBody. jsp?Y=2013\&M=02\&D=13\&ID=2013021300109. 